Pak. J. Anal. Environ. Chem. Vol. 21, No. 2 (2020) 179 - 192

\title{
Classification, Uses and Environmental Implications of Disinfectants
}

\author{
Fadim Yemiş ${ }^{1}$, Nilgün Yenil Harmanc1 ${ }^{2}$ \\ ${ }^{1}$ Manisa Celal Bayar University, Akhisar Vocational School, Department of Chemical and Chemical Processing \\ Technologies, 45200, Akhisar, Manisa-Turkey. \\ ${ }^{2}$ Manisa Celal Bayar University, Sciences and Arts Faculty, Department of Chemistry, 45030, Muradiye, \\ Manisa-Turkey. \\ *Corresponding Author Email: nilgun.yenil@cbu.edu.tr \\ Received 09 September 2020, Revised 11 December 2020, Accepted 10 December 2020
}

\begin{abstract}
Disinfectants are not only cleaning reagents such as soap or detergents but are hygienic materials prepared with the composition of various chemicals. Many classification routes are possible, but they are placed in two main groups, such as organic and inorganic disinfectants. The classification prevails for high level disinfectants and depends on chemical structure. In high-level disinfectants aldehydes, hydrogen peroxide, and chloride type chemicals are used. In contrast, alcohols, phenols, ammonium salts, and iodine solutions are recommended for low disinfectant applications. Soap, iodide, and alcohol solutions are the best antiseptic agents for hand and skin. Iodine-based solutions are good primary tissue and skin disinfectants. The alcohol solutions have a good inhibitory effect on many microorganisms, micro bacteria, fungi, and various viruses. These solution types are not hazardous to use as both antiseptic and surface disinfectants compared to many other chemicals.
\end{abstract}

Keywords: Organic disinfectants, Inorganic disinfectants, Hygienic materials, Disinfectant chemicals.

\section{Introduction}

Disinfectants are antimicrobial chemical reagents to achieve hygienic conditions and are used to eliminate and inactivate the risk of pathogen infection. Disinfectants can be a simple inorganic compound such as sodium hydroxide and sodium hypochlorite or a highly complex organic molecules, such as phenolics and quaternary ammonium salts [1, 2]. Therefore, the chemical contents of disinfectants consist of long list of chemical molecules. Although they can be classified in many ways, they can be placed in four basic classes according to their degree of affecting microorganisms, their mechanism of action, their area of use and their chemical structures [3-5]. Due to their strong chemical structure, they destroy many components of microorganisms. On the other hand, chemical classifications can be done in two main groups such as inorganic and organic disinfectants. While most of these viruses are beneficial, other ones are fatal pathogens. These viruses are the smallest living organisms, have only gene forms and feed on any living organisms. Even if a person is healthy, his/her body carries most of these viruses up to $1 / 100$ of their weight [6].

Proceeding: International Symposium for Environmental Science and Engineering Research 2020 held on 4-5 July 2020 online 
Most disinfectant formulations consist of different chemical components, including water, surfactants (detergents) and fragrances. They are also excellent cleaners and resistant or half-resistant chemicals [1].

A disinfectant shows effectiveness depending on basic parameters such as chemical feature, temperature, $\mathrm{pH}$, concentration and contacting time [7-12]. Additionally, the structure and functionality of the bacterial cell is important in the effectiveness of the disinfectant. Disinfectants have both extremely harmful effects as well as great benefits. Therefore, the proper selection of the disinfectant for its intended use is very important for human health and the environment.

In this review, some disinfectants, used in our life, are classified and examined in terms of their chemical and molecular structures. It is briefly explained in which areas they are used with their beneficial and harmful effects.

\section{Chemical Classification and Usage Areas of Disinfectants}

In the European Union, there are approximately 250 different chemicals used in the production of microbiocidal substances. A $1 / 3$ of these chemicals are widely used in disinfectant products. Many of these substances can be divided into different chemical groups. Basically, acids and alkalis, heavy metals and their salts. Some oxidant compounds are inorganic disinfectants. Any organic metal compounds and their salts, phenol, aldehyde and alcohol derivatives are termed as organic disinfectants. Some common active disinfectants can be known as hydrogen peroxide, sodium hypochlorite, chlorhexidine, chlorophene, triclosan, glutaraldehyde, ethyl alcohol, benzalkonium chloride [1, 2, 4, 13-15]. A simple flow chart of disinfectants classification, molecular formulas of some common chemical disinfectants and their spectrum of activities according to low, intermediate, high levels is given in Fig. 1, Table 1 and 2, respectively.

\section{Chlorine-based Disinfectants}

It is possible to list many inorganic and organic disinfectants that contain chlorine in their molecular structures. The most used derivatives are given here. For instance, hypochlorite solutions of different metals are known as inorganic disinfectant class. Sodium hypochlorite $(\mathrm{NaOCl})$ is the oldest and bestknown disinfectant against to all kind of microorganisms $[2,16]$. The properties of potassium hypochlorite $(\mathrm{KOCl})$ are very similar to sodium hypochlorite. They are available in liquid forms whereas calcium and lithium hypochlorite $(\mathrm{CaOCl}$ and $\mathrm{LiOCl})$ are solid forms [17].

Trichloroisocyanuric acid (TCICA) [18], sodium dichloroisocyanurate (NaDCC) [19] and $N$-chlorosuccinimide (NCSI) [20] can be listed as organic disinfectant compounds. These are other powder compounds like $\mathrm{CaOCl}$ that are an alternative source of chlorine and active chlorine to water in $90 \%$, $60 \%$ and $40 \%$, respectively [17].

This group of compounds are useful for high level disinfection because of their bactericidal and microbicidal effects. Generally, their low concentrations are enough to use. For example, hypochlorite for household bleach that is available as 5.25$6.15 \%$ concentration that is enough to dilute to $0.5-1 \%$ of the concentration and use as a disinfectant. Different $\mathrm{NaOCl}$ concentration provides different levels of disinfection. For high-level application, 1000-5000, for middle- 
level application 100-1000 and for low-level application $100 \mathrm{ppm}$ of it is used [4, 21]. All these are extremely reactive, inexpensive, environmentally friendly chemicals that are used in drinking water, swimming pools and simple surface disinfectants in many places such as houses, offices, schools and hospitals [22]. Their concentrated solutions are corrosive to skin, metals and other materials so they can cause skin and eye irritations. Excessive use of $\mathrm{NaOCl}$ causes chromosomal aberrations while NaDCC causes eye damage and skin burns $[2,4,17]$.

\section{Iodine-Based Disinfectants}

An iodophor is a combination of iodine with a solubilizing agent. The best-known and most widely used iodophor is povidone-iodine $[15,23-25]$. This iodine-based polyvinylpyrrolidone compound and other iodophors work as a good free iodine source in aqueous solutions while keeping the antiseptic activity of iodine.

Iodate and polyvinyl pyrrolidone are useful for intermediate and low-level disinfections, have bactericidal, tuberculocidal fungicidal and viricidal effects. Iodine-based disinfectants are health care agents as well as low cost like chlorine-based disinfectants. A mixture of $0.75 \%$ povidone iodate solution is used for hand disinfection as an antiseptic. Iodophors as organic disinfectants are used for cleaning medical equipment, endoscopes and thermometers in surgery and for skin and mucous membrane infections. Although it can cause serious skin irritation, burns, allergies, cough, respiratory distress and dizziness, it is used in preoperative skin cleaning and burns treatment $[2,4]$.

\section{Phenol-Based Disinfectants}

Phenol and its derivatives are good antiseptic and organic chemicals in the use of the surgery area. Many phenolics have been used as disinfectants in our life for 30 years. Two common phenol derivatives are $o$ phenlyphenol (OPP) and $o$-benzyl- $p$ chlorophenol (OBPCP) [26, 27]. Some of them are intermediate-level disinfectant and some are high-level disinfectant [28].

They are tuberculocidal, fungicidal, virucidal, and bactericidal. Phenolic compounds can be effective against the hepatitis B virus by long exposure time. A $0.5 \%$ of dilution of OPP and OBPCP mixture at certain percentages have been extremely successful in inactivating the HIV virus [2]. Different disinfectant compositions are available containing mixtures of different types of chemicals as well as different phenol mixtures used as bactericidal active compounds [29-30].

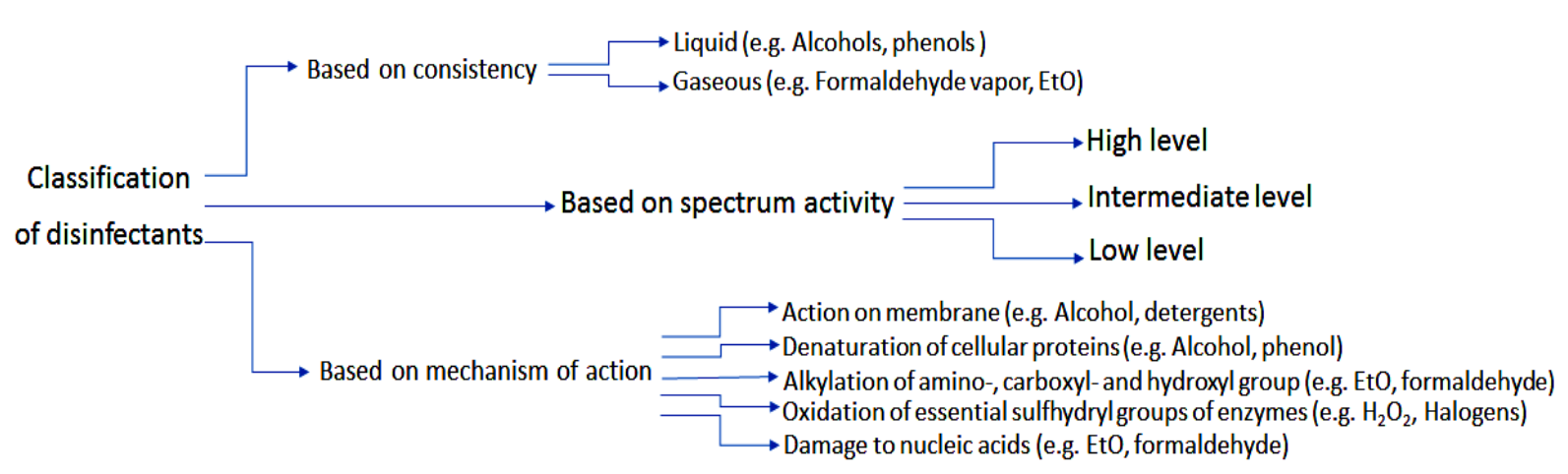

Figure 1. Classification of disinfectants 
Most complex compounds of phenol are used in disinfection applications. For example, chlorophene (CP) and hexachlorophene (HCP) (3\% in water) are fungicidal, tuberculocidal and virucidal. They are used for intermediate and low-level disinfection applications, and suitable for medical device disinfectant use and floor cleaning in hospital and environmental surfaces. They are highly toxic and cause many diseases such as adenoma, dermatitis and kidney $[17,31]$.

Triclosan (TC), a more moderate disinfectant, can be used in home cleaning. TC is suitable for use in cosmetics, oral hygiene, and dermatologic preparations as well as health care personnel handwashes. It is effective against gram positive bacteria and is ineffective against gram negative bacteria and viruses. The solution of $2 \% \mathrm{TC}$, which is not harmful, has antibacterial activity. Another common phenol-based disinfectant is $p$ chloro-m-xylenol (PCMX) that has highly alkaline $\mathrm{pH}$ and its $0.5-3.75 \%$ solutions. It is effective against gram positive bacteria and less effective against gram negative bacteria and some viruses. PCMX is used in antimicrobial soaps, its antimicrobial effectiveness is increased with EDTA addition [32].

\section{Aldehyde-Base Disinfectants}

Many aldehyde derivatives have antimicrobial characteristics. Some are also suitable for disinfection. The commonly known organic disinfectants of this group are formaldehyde (FA), glutaraldehyde (GA) and $o$-phthalaldehyde (OPA) [33]. They are highlevel disinfectants and are bactericidal, fungicidal, tuberculocidal and virusidal effective $[2,4,5]$. FA has perfect broadspectrum biocidal activity and $5 \%$ of the concentration is enough for disinfection of any surface. Cidex, prepared as commercially, is a perfect GA derivative disinfectant that is ten times more effective than FA and less toxic for human health. The $2 \%$ concentration of GA is enough to kill vegetative, micro, and sporoid bacteria $[2,4]$. OPA which is a $55 \%$ solution and has not any irritant effects for eyes and nasal passage has excellent properties against many microorganisms, including glutaraldehyde-resistant mycobacteria and $B$. atrophaeus spores and has great stability over a wide range of $\mathrm{pH}$ between 3 and 9 [4]. FA is used to sterilize surgical types of equipment and to prepare viral vaccines as embalming agents, whereas GA is used for disinfection of endoscopic, laparoscopic, haemodialysis equipment, bronchoscopy equipment and portable dental prostheses, as well as for cleaning the lenses. They are not corrosive, but may be toxic and cause severe eye, nose, throat and lung irritation, along with headaches, drowsiness and dizziness. They may cause asthma in long term exposure [34].

\section{Alcohol-Based Disinfectant}

Alcohols are a common functional group in organic chemistry. Some are excellent organic disinfectants and are frequently used in the healthcare surroundings [35]. Ethyl alcohol (EA) and isopropyl alcohols (IPA) [33] are potent against a variety of microorganisms in exposure periods ranging from $10 \mathrm{sec}$ to $1 \mathrm{~h}$. They are useful for intermediate and low-level disinfections and are bactericidal effective disinfectants and antiseptics and have also virucidal and tuberculocidal effects $[2,4]$. They are capable of inhibiting gram negative and gram-positive microorganisms, fungi, mycobacterium, herpes HIV, influenza and hepatitis B viruses. EA at concentrations of $60 \%-80 \%$ inhibits all the lipophilic viruses such as herpes, vaccinia, and influenza and many hydrophilic viruses such as adenovirus, enterovirus, rhinovirus, and rotaviruses. It does not effect on hepatitis A virus (HAV) 58 or poliovirus. IPA at a concentration of $20 \%$ can kill the cysts of 
Acanthamoeba culbertsoni like chlorhexidine and hydrogen peroxide [23].

As hand antisepsis, these alcohols can be used individually or on different combinations. For hand disinfection, EA in $70 \%$ and IPA in $60 \%$ are widely used, while single, double or triple combinations of them with higher percentage of alcohol are preferred for surface disinfection. The solution of EA in $70 \%$ is used for the disinfection of non-critic equipment's such as scissors, hospital files, stethoscope, thermometers of oral and rectal $[2,4]$.

EA causes celiac, Crohn's disease and ulcerative colitis. Acute kidney injury, autism, alcoholism, irritable bowel syndrome, lung cancer are ethanol-induced diseases. IPA and n-propyl alcohols cause drowsiness and dizziness and alcohol poisoning, dermatitis and allergic contact in addition to the diseases caused by ethanol [17].

\section{Quaternary Ammonium-Based Disinfectants and Biguanides}

Quaternary ammonium-based disinfectants and biguanides, are organic chemicals, which have cationic detergent properties. They are useful for intermediate and low-level disinfections and have fungicidal, bactericidal and virucidal effect against lipophilic viruses [36]. But they are not sporicidal and generally not tuberculocidal or virucidal against hydrophilic viruses $[2,4$, 17]. Although they are effective in grampositive bacteria, they are not effective in gram-negative bacteria [37].

In this group, the most used disinfectants are benzalkonium chloride (BAC), alkyl dimethyl benzyl ammonium chloride (ADMBAC) and cetyl-pyridinium chloride (CPyC). ADMBAC is a good disinfectant for cleaning non-critical surfaces such as stethoscope and blood pressure cuff so it is safely used in hospitals. They are very effective for disinfection of swimming pool and many hard surface cleanings, e.g. floor, furniture, walls. Normally all are also used as hand and body disinfection applications in hospital [31, 38].

They are used in hygienic and wet towel and as antibacterial finishing agent in textile industry. They are also used as antiseptic reagent for wounds and cuts in children. On the other hand, the overuse of BAC causes cornea carcinoma and occupantional asthma has been reported in a few clinical reports owing exposure to it $[17,36]$.

Chlorhexidine $(\mathrm{CH})$, the ammonium component, most active at $\mathrm{pH} 8$, is a biguanide structure. It is an antiseptic and disinfectant solution and is a mixture of $1.5 \%$ chlorhexidine and $15 \%$ cetrimide substances in alcohol and non-flammable. The $2 \% \mathrm{CH}$ in $70 \%$ IPA solution is an effective disinfectant use for surgical skin preparation [39]. It is effective as virucidal and inhibits herpes simplex virus (HSV), HIV, respiratory syncytial virus (RSV) and influenza viruses but it is not effective for rotavirus, adenovirus and enterovirus. $\mathrm{CH}$ has antiviral effects and perfect inhibition properties against HIV. It is reported that $4 \%$ and $0.5 \%$ solutions of $\mathrm{CH}$ in $70 \%$ alcohol is entirely inhibited by HIV-1 [9, 40, 41].

Its parent compound is not soluble in water so it's dihydrochloride, diacetate, and digluconate salts are used as disinfectants for skin and hands and in cosmetics as an additive reagent for creams, toothpaste, deodorants, and antiperspirants, and in pharmaceutical products as preservative compound in eyedrops, active substance in wound dressings and antiseptic mouthwashes. It can be safely used for oral rinses and skin cleaners at the low concentrations, but it can be harmful at high concentrations $[4,5,17]$. 


\section{Table 1. Molecular structures of disinfectants.}

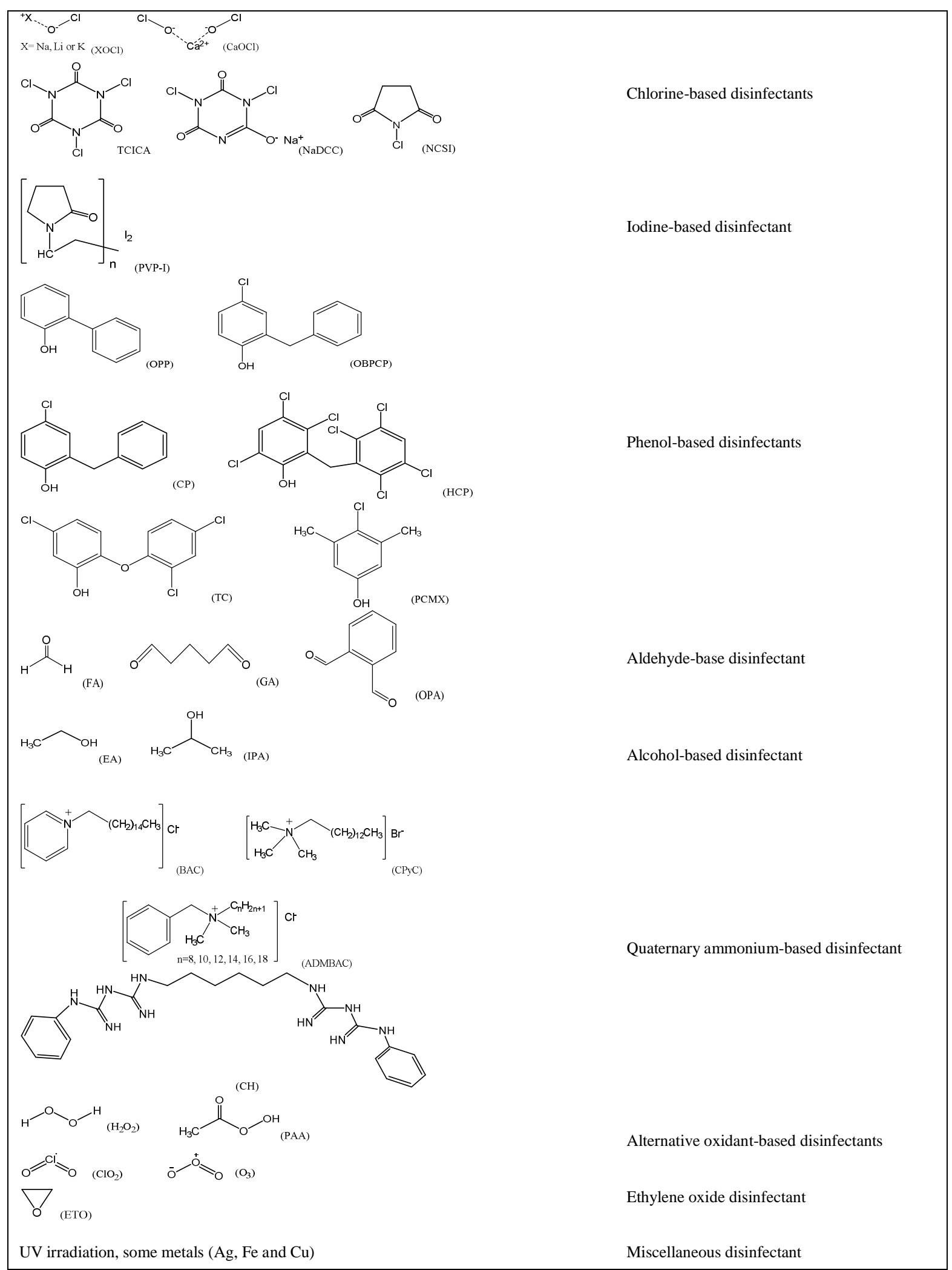




\section{Alternative Oxidant-Based Disinfectants}

Hydrogen peroxide $\left(\mathrm{H}_{2} \mathrm{O}_{2}\right)$, peracetic acid (PAA), chlorine dioxide $\left(\mathrm{ClO}_{2}\right)$ and ozone $\left(\mathrm{O}_{3}\right)$ are studied in this section as alternative oxidant chemicals that are used as application disinfectants [8, 42, 43].

$\mathrm{H}_{2} \mathrm{O}_{2}$, nontoxic, inorganic chemical and high-level disinfectant, has an excellent inhibition property to many microorganisms such as bacteria, fungi, viruses, spores and yeasts. For surface cleaning, its solution is suitable at a $7.5 \%$ concentration, and it is used in general cleaning disinfection processes at a 1-3\% concentration. It's solution at a $6 \%$ concentration is more successful than a $2 \%$ glutaraldehyde solution that is a high-level disinfectant for disinfection of flexible endoscopes. Commercially available concentration is $3 \%$, but different concentrations of it from $6 \%$ to $25 \%$ can be prepared for several purposes. While 3\% and/or $6 \%$ concentrations are used in the disinfection of soft contact lenses, they are effective at $7 \%$ concentration in some sports inhibition [4, 44]. It causes skin burns and eye damage because of its irritation properties. It can be observed to acute toxic effects by inhalation [17].

PAA (organic acid) is a high-level disinfectant that is effective in most microorganisms. It is expensive, corrosive, irritant for skin and eyes and not resistant but it does not turn into harmful for decomposition products. Although PAA is highly oxidizing reagent, it is an alternative use to $\mathrm{ClO}_{2}$ due to having high reactivity and weakly acidic features. Comparing with GA in cost, performance, and protection, PAA has the same clinical results. Thus, it can be safely used in different concertation ranges for medical, surgery and dentist equipment's disinfections. Additionally, it used in the food industry and the wastewater disinfection applications owing to having excellent antimicrobial activity. The commercial solution mixture of PAA and $\mathrm{H}_{2} \mathrm{O}_{2}$ is available at a $0.08 \%$ and $1.0 \%$ or $0.23 \%$ and $7.35 \%$ concentrations [2]. This oxidant-base mixture is completely effective on all bacterial spores, and all microorganisms and it deactivates mycobacteria that are resistant to GA. Toxic effects can be observed by contact and inhalation of it as like $\mathrm{H}_{2} \mathrm{O}_{2}[4,8,34$, 43, 45].

$\mathrm{ClO}_{2}$ is sensitive to light and highly oxidizing, corrosive and irritant chemicals. It, free chlorine source, is enough to shorten application about 5 minutes for high-level disinfection. The quantities above the limit level of it are very toxic for aquatic microorganisms [43, 46].

$\mathrm{O}_{3}$ is the alternative chlorine source and high-level disinfectant, but it needs energy and professional use so, it is expensive. It is used to apply in wastewater treatment to destroy organic micropollutants. The toxicity level of $\mathrm{O}_{3}$ for humans is not certain. Toxicity depend on many factors and shows different results on everyone. PAA, $\mathrm{ClO}_{2}$, and $\mathrm{O}_{3}$ are very effective against to protozoa comparing to free chlorine and the little by-products emerge [47].

\section{Ethylene Oxide Disinfectant}

Ethylene oxide (ETO), dissolves easily in water, is a flammable, explosive and toxic gas $[48,49]$. It is a base chemical to produce ethylene glycol that is found in antifreeze and polyester. Less than $1 \%$ amount of it is enough to control insects in some stored food and agricultural products and to sterilize medical equipment and supplies in hospitals.

ETO, effective for all microorganisms, provides sterilization by inversible alkalization in the cell walls of 
microorganisms. Mixtures of ETO with hydrochlorofluorocarbon (HCFC) and carbon dioxide $\left(\mathrm{CO}_{2}\right)$ are used for the sterilization to prevent the flammable and explosive features of ETO. It is suitable for the disinfection of many medical materials and is preferred for critical and semi-critical items such as heat and moisture sensitive plastic materials in hospitals or healthcare facilities [50].

It may cause skin and eye irritation, dizziness, nausea, headache, blisters, vomiting, coughing and difficulties of respiratory. Serious health problems such as spontaneous abortion, genetic defects, nerve damage, peripheral paralysis, muscle weakness, and memory damage occurs with exposure ETO [17].

\section{Miscellaneous Disinfectant}

Many compounds can be effective in disinfection as antimicrobial activity. Some metals, ultraviolet (UV) irradiation and pasteurization can be used as miscellaneous type disinfectants.

Metals, which have a perfect effect on several microorganisms, are suitable for some disinfection applications [51]. Metals such as silver $(\mathrm{Ag})$, iron $(\mathrm{Fe})$, and copper $(\mathrm{Cu})$ could be used for water disinfection or reusable medical devices [52]. Silver is used to treat conjunctivitis of the newborn. Bacteria on stainless steel surfaces can be inactivated by using silver and zinc ions. Copper-silver ionization can be used as disinfections application. Organic mercurial or preservative disinfectant type metal derivatives are commonly used in pharmaceuticals and cosmetics.

The use of UV radiation is a good disinfection application against many bacteria. On the UV irradiation at 240-280 nm bactericidal effect is maximum level. Mercury vapor is effective on destroying maximum microbes. UV radiation which kills bacteria and viruses not bacterial spores and decreases postoperative infection in the "refined clean" surgical procedures, is used in drinking water disinfection, titanium implants and contact lenses [53, 54].

Pasteurization that is the hot water disinfection at about $70{ }^{\circ} \mathrm{C}$, is an alternative application without using any chemicals. This is used for respiratory therapy and anaesthesia equipment. All pathogenic microorganisms are destroyed by pasteurization that are not effective on pathogenic spores $[55,56]$.

\section{Disinfectant's Veruse; Pandemic COVID-19}

Low, intermediate, and high-level disinfectants are toxic due to their high chemical contents. Great emphasis has been stated on high-level disinfections over the past few years; however, low and intermediatelevel disinfectants are enough to prevent infections in many applications of healthcare facilities. Since, overuse of many common chemicals as disinfectants can cause serious health problems such as skin, eye, and respiratory system irritations, as well as hormone imbalance, immune system effects, asthma, and potentially, reduced fertility. This problem has been a concern even before COVID-19, especially for the health care professionals. Most of the hospital-associated infections have been reported about catheters, ventilators, antibiotic therapy, inadequate hand hygiene and length of hospital stay [57].

According to the documented reports, the rate of elevated asthma and chronic obstructive pulmonary disease rates in the health care industry is higher than other industries. There are over 40 documented articles which show a positive correlation among cleaning products, specifically disinfectants used in hospitals cause problems 
for example asthma [58]. During the initial phase of the COVID-19 pandemic, most of the governments recommended the use of disinfectants not only on hands but the frequently touched surfaces and it subject led to a sharp increase in the disinfectant product purchases around the world. In accordance with a survey, after the pandemic, $45 \%$ of the US nationals spend more money to buy disinfectants and according to a Washington Post report, $39 \%$ of the US adults used these disinfectants in a risky way [59]. Chang et al., reported that in the US an increase of $20 \%$ in Poison center calls was reported in 2020 relative to the same period in 2019. There were 45, 500 reports of cleaners and disinfectants from January to March and this statistic is much higher than the same months in 2018 and 2019 [60].

The adverse effects of overuse of disinfectants on the consumers were reported in September 2020 by Ghaffari and et al., considering important parameters such as age, gender, education level and utilization [61]. The additional report related to the effects of disinfectant overuse on wildlife was offered by Nabi et. al. According to the authors' the pandemic trucks and drones in most parts of the world have been deployed to spray chemical disinfectants in urban areas [62]. Sprayed disinfectants can affect biodiversity due to contamination of the air, soil, and water.

The reality is that an ideal disinfectant is not yet available. Scientific guidelines are available for use of disinfectants in hospitals, but there are no guidelines available for largescale application of disinfectants therefore, disinfectants used in the urban environment should be selected in a way to avoid environmental pollution as well as harm to biodiversity. Users should be aware that all approved disinfectants are not safe for having a healthy life and should be careful about choosing an appropriate disinfectant. It is suggested for users to access the Material Safety Data Sheet (MSDS) on chemical disinfectants to minimize potential exposure, especially while selecting high-level groups.

It is very important to develop not only scientific guidelines for use of disinfectants on large scale but also to develop low-risk effective disinfectants [63-65].

Table 2. Spectrum activities of these chemical disinfectants.

\begin{tabular}{|c|c|c|c|c|c|c|c|c|}
\hline \multirow{2}{*}{ Chemical Disinfectants } & \multicolumn{3}{|c|}{ Based on spectrum activity } & \multicolumn{5}{|c|}{ Spectrum of activity } \\
\hline & Low & Intermediate & High & Vegetative cell & Mycobacteria & Spores & Fungi & Viruses \\
\hline Chlorine-based & & & $\bullet$ & + & + & - & + & + \\
\hline Iodine-based & $\bullet$ & - & & + & + & - & + & + \\
\hline Phenol-based & & $\bullet$ & $\bullet$ & + & + & - & + & + \\
\hline Aldehyde-based & & & $\bullet$ & + & + & + & + & + \\
\hline Alcohol-based & $\bullet$ & $\bullet$ & & + & $+/-$ & - & + & $+1-$ \\
\hline Quaternary ammonium-based & $\bullet$ & $\bullet$ & & + & $+/-$ & - & + & $+1-$ \\
\hline Alternative oxidant-based $\left(\mathrm{H}_{2} \mathrm{O}_{2}, \mathrm{PAA}, \mathrm{ClO}_{2}\right)$ & & & $\bullet$ &,,+++ &,,+++ &,,+++ &,,+++ &,,+++ \\
\hline Ethylene oxide & & & $\bullet$ & + & + & + & + & + \\
\hline Miscellaneous $\left(\mathrm{UV}^{\mathrm{c}}\right.$, Metals $^{\mathrm{b}}$, Pasteurization $\left.{ }^{\mathrm{a}}\right)$ & $\bullet^{\mathrm{c}, \mathrm{b}}$ & $\bullet^{c}$ & $\bullet^{\mathrm{a}}$ &,,+++ &,,+++ &,,-+- &,,+++ &,,+++ \\
\hline
\end{tabular}




\section{Conclusion}

We investigate the chemical structures and usage areas of some common disinfectants that are explained in nine subtitles, in this review.

Chlorine-based disinfectants as ecofriendly and cheap chemicals are suitable to use for surface disinfection because of their high-level disinfection properties against all kinds of microorganisms, whereas $\mathrm{ClO}_{2}$ and $\mathrm{O}_{3}$ which are alternative oxidant-based disinfectants are not suitable for use because they require professional use.

Iodine-based disinfectants are ecofriendly and low-cost organic compounds. They are not suitable for surface disinfection while comparing with chlorine-based ones and are widely used for medical equipment cleanings, surgery applications and mucous membrane infections owing to their low-level disinfection features.

Alcohol-based disinfectants which are non-toxic and eco-friendly chemicals are suitable to use for many healthcare applications. These disinfectant groups are not preferred to clean the surfaces such as floor, furniture and sink where there is application of the appropriate proportions of double or triple alcohols mixtures. Generally, they are used for hand and body disinfections with a single form of alcohols such as EA and IPA because of intermediate- and low-level disinfectant properties.

Phenol- and aldehyde-based disinfectants which have toxic effects are widely used in cosmetics, hospitals, operations of surgeries and dental, oral and dermatological solutions, and antimicrobial soaps owing to their intermediate- and highlevel effects against the microorganisms.
Quaternary ammonium-based disinfectants are widely used in hygienic and wet towels while their salt forms are preferred disinfectant reagents in cosmetics and pharmacy owing to their intermediate- and low-level disinfectant properties. They are very effective in cleaning hard surfaces and simple equipment in hospitals and using for hand and body disinfection applications. Their small combinations with alcohol can be used for excellent surgical skin disinfection.

Organic disinfectant PAA is used for medical, surgeries, and dentist devices while inorganic disinfectant $\mathrm{H}_{2} \mathrm{O}_{2}$ is preferred to use for surface cleaning, some simple equipment in hospitals, and in the cosmetic industry. Both are high-level disinfectants. Compared to $\mathrm{ClO}_{2}$ and GA, PAA can be used safely for medical, surgical, and dental equipment disinfectants in different concentration ranges. It is suitable disinfectant for food industry and cleaning of wastewater.

ETO is preferred to use for critical equipments such as heat and moisture sensitive plastics in hospital as well as protection of stored and agricultural food from insects in the industrial applications. It is not more toxic than the other chemicals but costs a lot. Various metals such as $\mathrm{Ag}, \mathrm{Fe}, \mathrm{Cu}$, even sometimes $\mathrm{Hg}$ in the other disinfectant group as miscellaneous are used for cleaning reusable equipments in hospitals, pharmacy and wastewater. Light radiation, especially UV radiation is a good disinfection method used in the surgical practice of doctors and dentists, as well as in disinfection of drinking water. Metals and their vapors, UV radiation are high-cost disinfection applications compared with pasteurization that is not expensive and requires only hot water without any chemicals and is applied easily everywhere. 
In summary, cleaning and disinfection should be fully effective, and their maximum contamination limit must be appropriated and regulated. Many disinfectants can be used unaccompanied and/or in different combinations. Sometimes, the use of disinfectants may be mandatory in our life to prevent our health problems even if most of them are chemicals. In fact, how chemicals protect our health is a big issue of conflict. The chemical which is used for disinfection will not be harmful if it is selected correctly and used in appropriate doses. Thus, disinfectants must be used in correct and appropriate concentrations and users should follow their use instructions. The degree of disinfection to affect the microorganism, its mechanism of action, usage areas and preparation should be well evaluated in terms of environment and human health.

To protect our health, these chemicals, which are known to have extremely harmful side effects, should be correctly evaluated with their beneficial and harm relationships. They should never be used instead of each other, otherwise many health problems and financial losses may be encountered.

The best way to destroy every virus or microbe which causes an epidemic is washing hands with soap. It's very obligatory to follow the same hygiene rules followed in coronavirus process, which is today's epidemic. Disinfection applications should be done properly, and interpersonal distance should be maintained against all virus dangers until a drug or vaccine is available to all.

\section{References}

1. G. Amy, R. Bull and G. F. Craun, $W H O$, EHC 216 (2004) 1. http://www.inchem.org/documents/ehc/e hc/ehc216.htm
2. W. A. Rutala, D. J. Weber and the Healthcare Infection Control Practice Advisory Committee (HICPAC), Guideline for Disinfection and Sterilization in Healthcare Facilities, 2008 (2019) 1.

https://www.cdc.gov/infectioncontrol/pd f/guidelines/disinfection-guidelines$\underline{\text { H.pdf }}$

3. C. R. Phillips and B. Warshowsky, Annual Rev. Microb., 12 (1958) 525. https://doi.org/10.1146/annurev.mi.12.10 $\underline{0158.002521}$

4. U. Abbasoğlu, Disinfectants: classification and aim of use, $6^{\text {th }}$ National Sterilization Disinfection Congress, Society of Disinfection Antisepsis Sterilization (DAS), 109 (2009).

https://www.das.org.tr/kitaplar/kitap200 9/pdf/109-

120\%20Ufuk\%20Abbasoglu.pdf

5. B. Kaşkatepe, Sterlization-disinfectiondisinfectants and impact mechanisms: Effect of physical agents on microorganisms, online lessons notes. https://acikders.ankara.edu.tr/pluginfile.p $\mathrm{hp} / 62731 / \mathrm{mod}$ resource/content $/ 5 / 7 . \% 2$ 0hafta\%20sterilizasyondezenfeksiyon.pdf

6. M. Mietzsch and M. AgbandjeMcKenna, Ann. Rev. Virol., 4 (2017) 3. https://doi.org/10.1146/annurev-vi-04071217-100011

7. P. S. Chang, L. J. Chen and Y. C. Wang, Aquaculture, 166 (1998) 1. https://doi.org/10.1016/S00448486(97)00238-X

8. J. Koivunen and H. Heinonen-Tanski, Water Res., 39 (2005) 1519. https://doi.org/10.1016/j.watres.2005.01. $\underline{021}$

9. P. Gelinas, J. Goulet, G. M. Tastayre and G. A. Picard, J. Food. Prot., 47 (1984) 841. 
https://doi.org/10.4315/0362-028X47.11.841

10. M. L. Johnson, L. Berger, L. Philips and R. Speare, Dis. Aquat. Org., 57 (2003) 255.

https://doi.org/10.3354/dao057255

11. V. S. Springthorpe and S. A. Sattar, $J$. AOAC Int., 88 (2005) 1. https://doi.org/10.1093/jaoac/88.1.182

12. P. S. Chang, L. J. Chen and Y. C. Wang, Aquaculture, 166 (1998) 1.

https://doi.org/10.1016/S0044$\underline{\text { 8486(97)00238-X }}$

13. G. McDonnell and A. D. Russell, Clin. Microbiol. Rev., 12 (1999) 147. https://www.ncbi.nlm.nih.gov/pmc/articl es/PMC88971/

14. R. Saito, M. A. Virji, P. K. Henneberger, M. J. Humann, R. F. LeBouf, M. L. Stanton, X. Liang and A. B. Stefaniak, Am. J. Indust. Med., 58 (2015) 101. https://doi.org/10.1002/ajim.22393

15. D. J. Jeffrey, Rev. Sci. Tech., 14 (1995) 57.

https://doi.org/10.20506/rst.14.1.828

16. J. V. Bueren, R. A. Simpson, H. Salman, H. D. Farrelly and B. D. Cookson, Epidemiol. Infect., 115 (1995) 567. https://doi.org/10.1017/S095026880005 8738

17. $\underline{\text { https://pubchem.ncbi.nlm.nih.gov/ }}$

18. X. Nie, X. Wang, J. Chen, V. Zitko and T. An, Environ. Toxicol. Chem., 27 (2009) 1. https://doi.org/10.1897/07-028.1

19. I. Heling, I. Rotstein, T. Dinur, Y. Szwec-Levine and D. Steinberg, $J$. Endod., 27 (2001) 278. https://doi.org/10.1097/00004770200104000-00009

20. A. R. A. Samarkandy, S. A. Al-Thabaiti and A. H. A. El-Bellihi, Mat. Sci. Res. India, 2 (2008) 219.

http://materialsciencejournal.org/pdf/vol 5no2/MSRIVol05N2P219-226.pdf
21. M. Orhan and Ö. Onan, Use of disinfectants and antiseptics, online subject, Bilkent University Health Center (2010) 1.

http://bilheal.bilkent.edu.tr/aykonu/ay20 10/nisan10/dezenfektan.htm

22. C. J. Holmes, A. Degremont, W. Kubey, P. Straka and N. K. Man, Blood Purif., 22 (2004) 461. https://doi.org/10.1159/000080791

23. H. Verstraelen, R. Verhelst, K. Roelens and M. Temmerman, BMC Infect. Dis., 12 (2012) 148. http://www.biomedcentral.com/14712334/12/148

24. E. M. Smith, M. J. Plewa, C. L. Lindell, S. D. Richardson and W. A. Mitch, Environ. Sci. Technol., 44 (2010) 8446. https://doi.org/10.1021/es102746u

25. S. Punyani, P. Narayana, H. Singh and P. Vasudevan, J. Sci. Ind. Res., 65 (2006) 116.

http://nopr.niscair.res.in/handle/1234567 $\underline{89 / 4805}$

26. F. J. Butt and C. L. Moyle, US Patent, US 3, 002, 883 (1961).

27. S. S. Block, Disinfection, Sterilization, and Prezervation, Lippincoat Williams and Wilkins, USA, Chapter 13 (2008) 255.

https://books.google.com.tr/books?hl=tr $\& 1 \mathrm{r}=\& \mathrm{id}=3 \mathrm{f}-$

kPJ17_TYC\&oi $=$ fnd $\& p g=P A 255 \& d q=0$ -benzyl-p-

chlorophenol+(OBPCP $)+\&$ ots $=\mathrm{KnIsFv}$ PJZ\&sig=vwr5FYVMi00sCLy8712o7h MhJng\&redir_esc $=\mathrm{y} \# \mathrm{v}=$ onepage $\& \mathrm{q}=0-$ benzyl-pchlorophenol\%20(OBPCP)\&f=false

28. D. Amsterdam and B. E. Ostrov, Disinfectants and antiseptics: Modes of action, mechanisms of resistance, and testing regimens, Antibiotics in Laboratory Medicine, 6 Ed. Chapter 12, Wolters Kluwer Health Adis (ESP) Publishing, Amsterdam (2014). 
https://doctorlib.info/pharmacology/anti biotics-laboratory-medicine/13.html

29. T. G. Hyde and F. Lamb, UK Patent Application, GB 2138683 A, Switzerland (1984).

30. M. D. Giuliano Agolini, P. D. A. Russo and M. D. M. Clementi, Am. J. Infect. Control, 27 (1999) 236.

https://doi.org/10.1053/ic.1999.v27.a909 $\underline{11}$

31. G. McDonnell and A. D. Russel, Clin. Microbiol. Rev., 12 (1999) 147. https://doi.org/10.1128/CMR.12.1.147

32. A. P. V. Wezel and T. Jager, Chemosphere, 47 (2002) 1113. https://doi.org/10.1016/S00456535(02)00048-6

33. W. W. Bond, M. S. Favero, N. J. Petersen and J. W. Ebert, J. Clin. Microbiol., 18 (1983) 535.

https://jcm.asm.org/content/18/3/535.sho $\underline{\mathrm{rt}}$

34. C. J. Holmes, A. Degremont, W. Kubey, P. Straka and N. K. Man, Blood Purif., 22 (2004) 461. https://doi.org/10.1159/000080791

35. H. F. Rabenau, G. Kamf, J. Cinati and H. W. Doerr, J. Hosp. Infect., 61 (2005) 107.

https://doi.org/10.1016/j.jhin.2004.12.02 $\underline{3}$

36. M. L. Jonhson, L. Berger, L. Philips and R. Speare, Dis. Aquat. Organ., 57 (2003) 255.

https://doi.org/10.3354/dao057255

37. S. Wessels and H. Ingmer, Regul. Toxicol. Pharmacol., 67 (2013) 456. https://doi.org/10.1016/j.yrtph.2013.09.0 $\underline{06}$

38. V. S. Sipringthore, S. A. Sattar, J. AOAC Int., 88 (2005) 1.

https://academic.oup.com/jaoac/issue/88/1

39. G. Moore, S. Schelenz, A. M. Borman, E. M. Johnson and C. S. Brown, J. Hosp. Infect., 97 (2017) 371. https://doi.org/10.1016/j.jhin.2017.08.019
40. K. Hoelzer, W. Fanaselle, R. Pouillot, J. M. Van Doren and S. Dennis, J. Food Prot., 76 (2013) 1006. https://doi.org/10.4315/0362-028X.JFP12-438

41. P. G. Mazzola, A. F. Jozala, L. C. L. Novaes, P. Moriel and T. C. V. Penna, Braz. J. Pharm. Sci., 45 (2009) 2. https://doi.org/10.1590/S1984$\underline{82502009000200008}$

42. N. Omidbakhsh, Am. J. Infect. Control, 34 (2006) 571.

https://doi.org/10.1016/j.ajic.2006.02.003

43. T. Kohn, L. Decrey and B. Vinneras, Michigan State University, E. Lansing, MI, UNESCO (2017) 1. https://doi.org/10.14321/waterpathogens. $\underline{71}$

44. D. N: Kramer, M. Stevenson, S. Kramer and P. Ardmore, US Patent, 5, 320, 805 (1994)

45. Regulation (EU) No 528/2012, Assessment Report, Finland (2016) 1. https://www.echa.europa.eu/documents/ 10162/8a848101-7853-2672-be2e49a5475a0c64

46. G. Svecevicius, J. Syvokiene, P. Stasiünaite and L. Mickeniene, Environ. Sci. Pollut. Res., 12 (2005) 302. https://link.springer.com/content/pdf/10. 1065/espr2005.04.248

47. T. J. Swanson, J. Zohib and J. Chapman, Ozone Toxicity, Book from Stat Pearls Publishing, Treasure, Island (FL) (2017).

https://europepmc.org/article/med/28613 $\underline{502}$

48. E. G. Star, J. Caselitz and T. Löning, Europe PMC, 170 (1980) 539.

https://europepmc.org/article/med/74242 $\underline{89}$

49. D. L. Lachenmeier, Side Effects of Drugs Annual, Chapter 22, (2016) 211. https://doi.org/10.1016/bs.seda.2016.07. $\underline{006}$

50. W. A. Rutala and D. J. Weber and the Healthcare Infection Control Practices 
Advisory Committee, HICPAC 2b (2002) 1 . http://hica.jp/cdcguideline/dsguide.pdf

51. K. Chamakura, R. Perez-Ballestero, Z. Luo, S. Bashir and J. Liu, Colloids Surf. B: Biointerfaces, 84 (2011) 88. https://doi.org/10.1016/j.colsurfb.2010.1 $\underline{2.020}$

52. A. B. Arata, US Patent, 6, 197, 814, B1 (2001)

53. X. Wang, X. Hu, H. Wang and C. Hu, Water Res., 46 (2012) 1225. https://doi.org/10.1016/j.watres.2011.12. $\underline{027}$

54. A. Yaşar, N. Ahmad, H. Latif and A. A. A. Khan, Ozone-Sci. Eng., 29 (2007) 485.

https://doi.org/10.1080/01919510701617 $\underline{710}$

55. H. Ahiley, R. Bentham and M. H. Brown, Front. Microbiol., (2017). https://doi.org/10.3389/fmicb.2017.01330

56. M. L. Barı, K. Enomoto, D. Nei and S. Kawamoto, J. Food Prot., 73 (2010) 752.

https://doi.org/10.4315/0362-028X73.4.752

57. E. Pechter and K. D. Rosenman, Am. J. Infect. Control, 44 (2016) 1755. https://doi.org/10.1016/j.ajic.2016.08.02 0

58. M. M. Quinn and P. K. Henneberger, Am. J. Infect. Control, 43 (2015) 424. https://doi.org/10.1016/j.ajic.2015.01.02 $\underline{9}$

59. L. Searing, The Washington Post, Democracy Dies in Darkness (2020). https://www.washingtonpost.com/health/ since-the-pandemic-39-percent-ofamericans-use-cleansers-anddisinfectants-in-riskyways/2020/06/12/64e80fba-abf6-11ea9063-e69bd6520940_story.html
60. A. Chang, A. H. Schnall, R. Law, A. C. Bronstein, J. M. Marraffa, H. A. Spiller, H. L. Hays, A. R. Funk, M. MercurioZappala, D. P. Calello, A. Aleguas, D. J. Borys, T. Boehmer and E. Svendsen, Morb. Mortal. Wkly. Rep., 69 (2020) 496.

http://dx.doi.org/10.15585/mmwr.mm69 $16 \mathrm{e} 1$

61. K. Dindarloo, T. Aghamolaei, A. Ghanbarnejad, H. Turki, S. Hoseinvandtabar, H. Pasalari and H. R. Ghaffari, J. Environ. Health Sci. Eng., 18 (2020) 1301. https://doi.org/10.1007/s40201-02000548-y

62. G. Nabi, Y. Wang, Y. Hao, S. Khan, Y. Wu and D. Li, Environ. Res., 188 (2020) https://doi.org/10.1016/j.envres.2020.10 9916

63. World Health Organization WHO Characterizes COVID-19 as a Pandemic (2020).

https://www.who.int/emergencies/diseas es/novel-coronavirus-2019/events-asthey-happen

64. S. P. Adhikari, S. Meng, Y.J. Wu, Y. P. Mao, R. X.Ye, Q. Z. Wang, C. Sun, S. Sylvia, S. Rozelle, H. Raat and H. Zhou, Infect. Dis. Poverty, 9 (2020) 29. https://doi.org/10.1186/s40249-02000646-x

65. O. Atolani, M. T. Baker,O. S. Adeyemi, I. R. Olanrewaju, A. A. Hamid, O. M. Ameen, S. O. Oguntoye and L. A. Usman, Exper. Clin. J., 19 (2020) 785. http://dx.doi.org/10.17179/excli20202349 